\title{
Code Switching in Sons and Lovers
}

\author{
Dimin Luo \\ The College of Foreign Languages, Yunnan Agricultural University, Kunming, China \\ Email: luodimin@163.com
}

Received July $14^{\text {th }}, 2013$; revised August $18^{\text {th }}, 2013$; accepted October $9^{\text {th }}, 2013$

\begin{abstract}
Copyright (C) 2013 Dimin Luo. This is an open access article distributed under the Creative Commons Attribution License, which permits unrestricted use, distribution, and reproduction in any medium, provided the original work is properly cited.
\end{abstract}

\begin{abstract}
Lawrence's writing is heavily influenced by his social background. He is in an incompatible family, for his parents come from different social classes. His sensitiveness to class distinctions brought about by his family background is deeply rooted in his writings. Novel Sons and Lovers is this typical work. One of the distinctive features of the novel is the use of two language varieties which expresses the bilingual situation of the Morels' family in Sons and Lovers. The writer Lawrence alternatively uses two language varieties in dialogues to reveal the psychology of the characters and the most characteristic of his theme: class conflict. This study researches into the use of language varieties of three major characters (Mr. Morel, Mrs. Morel and their son Paul) in Sons and Lovers from the viewpoint of code switching to discover how class conflict is presented by alternative use of language varieties. To appreciate and deeply understand the novel, it is necessary to know the application of code switching in this work.
\end{abstract}

Keywords: Code Switching; Sons and Lovers; Language Variety; Class Conflict

\section{Introduction}

With the fast development of sociolinguistics, the research field about code switching has spread into many fields. It as one of the essential parts of sociolinguistics is drawing more and more attention from grammarians, sociolinguists, psychologists, anthropological linguists and so on.

This study investigates into the instances of code-switching in Sons and Lovers. The famous British writer David Herbert Richards Lawrence is quite sensitive to the conflict distinctions. Sons and Lovers manifests this theme. It is estimated that about $50 \%$ of the novel is conversations. If readers only realize the code switching in the conversation but don't dig out the connotative meaning of the switching, they may not really understand the novel. Only when they devote to reading the novel, may they really appreciate the great work. Thus, the analysis of code switching in the novel is necessary. It may help the readers develop a better understanding of code-switching in literature and arouse the interest of language teachers and learners to pay attention to the language phenomenon.

\section{Code Switching and Literature}

In the past, one dominant view towards code switching stated that it could not be counted as a research topic. The earlier studies of language in contact largely considered code switching as an inference phenomenon, "the performance of the imperfect bilingual, motivated by inability to carry on a conversation in the language on the floor at the moment" (Scotton, 1993: pp. 47-48), while now code switching is so widely studied, drawing more and more attention from scholars at home and abroad in different areas. The following part will discuss the significance of the theory and the research.

\section{Theory of Code Switching}

\section{Definition of Code Switching}

From different perspectives, many scholars give quite a few definitions to this term. R. A. Hudson regards code switching as the inevitable consequence of bilingualism (or multilingualism). Anyone who speaks more than one language chooses between them according to circumstances (Huston, 2007: p. 51). Woolard defines code switching as an individual's use of two or more language varieties in the same speech event or exchange (Woolard, 2004: p. 73). These definitions show that bilingual or multilingual speakers may change their language because of some situations or their intentions.

\section{Influential Theory of Code Switching}

In their study of switching between standard and local dialect in the Norwegian village of Hemnesberget, Blom and Gumperz showed the systematic communication of specific social information through code switches (Blom \& Gumperz, 1972: p. 305). They also proposed a functional distinction between situational and metaphorical code switching that is still a point of departure for most researchers.

In situational switching, a change of language signals a change in the definition of the speech event, involving "clear changes in the participants" definition of each other's rights and obligation" (Blom \& Gumperz, 1972: p. 424). And R. A. Husdon believes that the switches between languages always coincide with changes from one external situation (for example, talking to members of the family) to another (for example, talking to the neighbours) (Hudson, 2007: p. 52). Thus, to some extent, the situation decides the language. For example, an English teacher in Yunnan high school chatted with her students before and after class in Yunnan dialect but lectured in 
English or Putonghua.

As or metaphorical switching, it is later encompassed under the label of conversational code switching and is a change in language that does not signal a change in the definition of the fundamental speech event. Interactants do not alter the basic definition of the rights and obligations in operation, but only allude to different relationships that they also hold (Bloom and Gumperz, 1972: p. 425). Such allusion is achieved through transient use of a language that serves as a "metaphor" for another social relationship regularly associated with it. The situation is less clear, either because it is ambiguous or because the speaker decides to ignore the observable external situation and focus instead on less observable characteristics of the people concerned. (Blom \& Gumperz, 1972: p. 426) In such cases, it is the choice of language that determines the situation. A common example is for a mother to tell her child to do something in one language, and then, if the child fails to obey, to switch to another language, thereby showing her stronger emphasis or displeasure. The switch shows the change of the situation.

\section{Function of Code Switching}

The above discussion reveals that switch between languages can signal the speaker's attitude towards the listener-friendly, irritated, distant, ironic, jocular and so on. If two bilinguals normally talk to each other in language $\mathrm{X}$, the choice of $\mathrm{Y}$ is bound to create a special effect. Besides, to some extent, such switches can reveal one's social status or roles.

\section{The Research of Code Switching and Literature}

With the fast development of sociolinguistics, its research field spreads widely, such as advertisement language, teaching approach, legal language. And it surely influences our literature. Especially, the code switching plays an important role in it. The scholars abroad or at home have made some contributions on the combination with code switching and literature.

In Western countries, Fennell and Bennett analyzed the elements of ridiculousness in John Kennedy Toole's work "Confederacy of Dunces" with the conceptions of sociolinguistics, such as code-switching. Peter Melman analyzed a kind of code switching in Shakespeare's play "Julius Caesar" to dig out the characters' internal world. What's more, sociolinguistics also was used in the analysis of the female work. The representative was the analysis of Virginia Woolf's work "To the Lighthouse" from the sociolinguistic perspective.

In China, scholars pay more attention to the varieties of the language in the literature work, namely the application of the dialects. And its research targets are usually novels and plays. The researchers often explore the effects and intentions of the use of the dialects. The research content is all too often the characters' conversations (Zhai, 1998).

\section{Code Switching Analysis of Sons and Lovers}

\section{Brief Introduction of Sons and Lovers}

In Sons and Lovers, Mrs. Morel and Mr. Morel were born in different classes. "Mrs. Morel came of a good old burgher family, famous independents who had fought with Colonel Hutchinson, and who remained stout Congregationalists. Her grandfather had gone bankrupt in the lace-marketat a time when so many lace-manufacturers were ruined in Nottingham. Her father, George Coppard, was an engineer - a large, handsome, haughty man, proud of his fair skin and blue eyes, but more proud of his integrity. Gertrude resembled her mother in her small build. But her temper, proud and unyielding, she had from the Coppards." (Lawrence, 1992: p. 6). She was well-educated, bright, high-hearted and religious.

On the contrary, Mr. Morel was born in a miner family and stopped schooling to work in the mine when he was just ten years old. He was poorly educated, lack of knowledge and rude in behaviour. He impressed the people that he was a heavy drinker, four-letter and irresponsible for his family.

Mrs. Morel's dream was to have a highly spiritual life, while Mr. Morel provided her a kind of completely realistic life, which is entirely different from Mrs. Morel's morality and religious thoughts. The torture of the life broke her dream. Because of this distinct social background and the degree of education, they had different philosophies and values. Thus, they quarrelled with each other quite often. After the quarrels, she was disappointed and depressed. She despised her husband. Therefore, she transferred her whole love to her sons. At the beginning, it was William, and then Paul. Her love to the sons, especially Paul, made a great impact on his life and love.

\section{Bilingualism in Morels'}

It has been observed that in some speech communities, two languages are used side by side with each having a different role to play; and language switching occurs when the situation changes. This constitutes the situation of bilingualism (Dai \& $\mathrm{He}, 2002:$ p. 124). One of the distinctive features of the novel is the use of two language varieties which expresses the bilingual situation of the Morel family in Sons and Lovers. The following part analyses the three main characters' language varieties (Mr. Morel, Mrs. Morel, their son Paul).

\section{Mr. Morel's Language}

Mr. Morel spoke the local dialect (the local miners' language). There are some common features in Mr. Morel's speech community. Generally speaking, it can be concluded as the following.

1) Ellipsis on pronunciation

a) Wrong pronunciation of $/ \mathrm{y} /$

The velar $/ \mathrm{y} /$ is pronounced as the nasal $/ \mathrm{n} /$. For example, they pronounce "going" as "goin", "waiting" as "waitin", "talking" as "talking" and so on.

b) Silence of the beginning sound $/ \mathrm{h} /$

For some words, their first sound $/ \mathrm{h} /$ is silent. For instance, they pronounce "hear" as "ear", "have" as "ave", "happen" as "appen" and so on.

c) Silence of consonant

In some situation, they don't pronounce some consonants of the words, such as, "and" as "an", "stand" as "stan".

d) Ellipsis on the unstressed close syllables

Sometimes, they may leave out the unstressed close syllables, "because" as "cause", "occasion" as "casino" and so on.

e) Ellipsis or mistakes on vowels

On occasion, they may make some mistakes on vowels. For example, they pronounce "yes" as "yis", "should" as "sh'lt", and "the" as "th" and so on.

2) Mistakes on Grammars

Double negative expressing the negative:

For instance, they express "I don't want nothing (Lawrence, 1992: p. 67)" as the meaning of "I don't want anything". 
3) Use of "thee" and "thou"

In this situation, the outdated language shows the poor education of the speakers.

All of these indicate that Mr. Morel is really poorly educated, and his language is lower than the standard language. The dialects lack the prestige, while standard language owns higher prestige. Thus, this also reveals Mr. Morel's low social status.

\section{Mrs. Morel's Language}

She used the Standard English (also called Queen's English) which has a higher prestige outside the mine district. Mrs. Morel's standard pronunciation made her more predominant in front of the persons who were lower than her. For example, after her son William fought against her classmate, when Mrs. Morel conversed with the opposite's, her superior pronunciation let people feel her excellence.

In their family, once Mr. Morel and Mrs. Morel contended the rights in their family, which reflects Mrs. Morel's superiority.

"What!" cried Mrs. Morel, panting with rage.

"You shall not touch him for her telling, you shall not". "shonna I?" shouted Morel

"Only dare!" she said in a loud, ringing voice.

"Only dare, milord, to lay a finger on that child! You'll regret it forever."

(Lawrence, 1992: p. 52).

This is a quarrel between the couple of Morel, which indicates not only the differences of their opinions but also their largely different languages. One is the Standard English which is applied by the middle or the higher classes, and the other one is the miners' dialects, which states that the two persons are from the absolutely different world.

In this quarrel, Mrs. Morel got the family's dominant right. Not only she but also her three children learnt to speak Standard English and studied French which was suggested by the higher class.

\section{Paul's Language}

Under his mother's influence or because of the Oedipus, Paul despised his father and kept distance with his father. This gap can be manifested in the conversation. When Paul went to tell his father about William's illness, it reveals their incompatibility.

"Is it thee, Paul? Is'e worse?"

"You've got to go to London?"

"E's niver gonge, child?"

"Yes."

"When wor't?"

"Last night we had a telegram from my mother."

(Lawrence, 1992: p. 136)

Their Languages indicate their social roles. Languages usually demonstrate and form the social identity. Gumperz believes that communication of social information presupposes the existence of regular relationships between language usage and social structure (Gumperz, 1986: p. 220). Different varieties impress listeners in different ways. People have diverse attitudes toward the languages. Hudson regards that the difference between language (standard variety) and dialect (non-standard) is that standard variety owns the prestige over the non-standard variety (Huston, 2007). For the Standard English, it is a term generally applied to a form of the English language that is normative for educated speakers. It is usually used in writing works and closely related to the "well-educated" persons. Since Standard English is a kind of standard, the non-standard English is considered as the "poorly-educated" or poor persons' languages.

\section{Code-Switching Analysis of Sons and Lovers}

According to the above content, we know that the dominant feature of Sons and Lovers is the bilingualism. Mr. Morel speaks the dialect of Bestwood; Mrs. Morel masters the standard language; Paul can grasp both of the languages. Nevertheless, most of the time, Paul follows his mother to speak the standard language. In this novel, there are many code switches. The switch between languages can signal the speaker's attitude towards the listener-friendly, irritated, ironic, humorous and so on. And the change of language is bound to create a special effect. Besides, it also reveals the social status of the speakers.

\section{Mr. Morel’s Code-Switching}

\section{1) Switching language to attract Mrs. Morel}

Mr. Morel followed miner's dialect. Actually, he could say some Standard English. When he met Mr. Morel at the first time, he attempted to approach Mrs. Morel's language to enter into her world. Standard English as a higher prestige language may impress her more deeply. In Chapter 1, it is obvious to discover his such effort.

"Now do come and have this one wi'me," he said caressively. "It's easy, you know. I'm pining to see you dance."

"No, I won't dance," she said softly. Her words came clean and ringing.

...

"I'm like a pig's tail, I curl because I canna help it," he laughed, rather boisterously.

(Lawrence, 1992: p. 12)

This switch indicates that actually Mr. Morel realized the prestige of Standard English at that time. He intended to use language to upgrade his social status.

2) Switching languages to emphasize his existence

Mr. Morel "stole" his wife's money and left, but some days later he came back and wanted to be impressive. He said in his wife's language on purpose:

"You may thank your stars I've come back tonight."

(Lawrence, 1992: p. 125)

In this family, if he wished to emphasize something, he had to imitate his wife's language, for his wife's status was higher than his. Therefore, he had to utter Mrs. Morel's Standard English.

\section{Mrs. Morel's Code Switching}

Disappointed to her husband, she began to look down upon his language. She refused to accept that language and also didn't allow her children to do that.

However, when she got angry, sometimes she would utter some Mr. Morel's language. When the children made her feel annoyed, she called them "babeys". When she was upseted by her husband, she usually said:

"Goodness, man, don't be so lachrymose", "Shut that 
doo-er!" he shouted, so that he could be heard down the Bottoms.

(Lawrence, 1992: p. 47)

"It's a pity, poor nesh creature!" Mrs. Morel said quietly.

(Lawrence, 1992: pp. 51-52)

In this family, Mr. Morel imitated his wife's standard language to stress his existence and satire her, while Mrs. Morel used his husband's dialect to laugh at him. Both of them mocked each other's identity with languages.

\section{Paul's Code-Switching}

Paul could grasp both languages. When he was young, he was largely influenced by his mother. Thus, mostly he spoke the standard language. While, with his body and thoughts becoming more mature, his male status in the society has been clearer and clearer. And his father is the person he wanted to imitate, especially his language. So, once he used his father's language to show his male role. In chapter seven, Paul and Klara went to date in Clifton Grove. Feeling quite quiet, he used his father's language for the first time.

"Your flowers are smashed," he said.

She looked at him heavily as she put back her hair. Suddenly he put his finger-tips on her cheek.

"Why dost look so heavy?" he reproached her.

She smiled sadly, as if she felt alone in herself. He caressed her cheek with his fingers, and kissed her.

"Nay!" he said. "Never thee bother!"

...

"But tha shouldna worrit!" he said softly, pleading.

...

"Yea, tha does! Dunna thee worrit," he implored, caressing. ...

(Lawrence, 1992: p. 309)

At the beginning, he just used a little father's dialect: "Why dost look so heavy?" While, after a short time, he expressed himself in idiomatic dialects: "Yea, the does! Dunna thee worrit". His language became more masterly. Why? Because when he was with his lovely woman, his male identity was aroused, he wanted to imitate his father as the true man.

This code-switching demonstrates the character's conscious change. Via this code switching, the psychological consciousness is expressed more clearly. And readers may better appreciate Lawrence's writing skills or styles.

\section{Conclusion}

Novelists shape the persons through the person's language.
Literature language is not cloud-built but from our social life. Thus, understanding the novel with the sociolinguistics, like the instances code switching in Sons and Lovers, may help you go deeply about the thoughts and skills of the novel. An awareness of this area will be of great benefit to the language learners in terms of providing them with possible and efficient strategies in communicating with the native speakers in the target language. Through the exchange of the different switches, the psychology of the characters in the work is deeply embodied. The use of the different code switching is an effective tool of describing the psychological change of the characters. This makes the novel truer and adds the aesthetic implication.

However, except the conscious activity expressed by code switching in literary work, there are still some parts for us to develop, such as the aesthetic effect of code switching in it.

\section{Acknowledgements}

The author is greatly indebted to the subjects for their friendly and honest participation in this study. Special thanks to her supervisor Prof. Lisheng Li, whose instruction and encouragement has contributed greatly to the completion of the paper. The author is also grateful for Prof. Hu Deying for his helpful suggestions. Many thanks to my husband, Mr. Bo zhao, the $\mathrm{PhD}$ candidate of the Chinese academy of sciences for his great encouragement. Sincere gratitude goes to the anonymous reviewer for his/ her valuable revising suggestions on this paper.

\section{REFERENCES}

Blom, J. P., \& Gumperz J. (1972). Social meaing in linguistic structure: Code-switching in Norway. In J. Gumperz, \& D. Hymes (Eds.), Directions in sociolinguistics. New York: Holt, Rinehart and Winston.

Dai, W. D., \& He, Z. X. (2002). A new concise course on linguistics for students of English. Shanghai: Shanghai Foreign Language Education Press.

Gumperz, J. (1986). Communicative competence revisited. Berkeley: University of California.

Hudson, R. A. (2007). Sociolinguistics. Beijing: Foreign Language Teaching and Research Press.

Lawrence, D. H. (1992). Sons and lovers. Beijing: Foreign Language Teaching and Research Press.

Scotton, C. M. (1993). Social motiations for codeswitching. Oxford \& New York: Oxford University Press.

Woolard, K. A. (2004). Codeswitching. In A. Durantic (Ed.), A companion to linguistic anthropology. Malden: Blackwell Publishing.

Zhai, Y. N. (1998) The analysis and study on code-switching in literary works. MA Thesis, Xi'an: Northwestern Polytechnical University. 